\title{
HEAVY METAL RESISTANCE OF MICROORGANISMS ISOLATED FROM COAL MINING ENVIRONMENTS OF SANTA CATARINA
}

\author{
Marcus Adonai Castro-Silva*; André Oliveira de Souza Lima; Ana Valéria Gerchenski; Daniela Batista Jaques; \\ André Luis Rodrigues; Pricila Lima de Souza; Leonardo Rubi Rörig
}

Laboratório de Microbiologia Aplicada, Centro de Ciências Tecnológicas da Terra e do Mar, Universidade do Vale do Itajaí, Itajaí, SC, Brasil.

This paper corresponds to an "extended abstract" selected for oral presentation in the $22^{\text {nd }}$ Brazilian Congress of Microbiology, held in Florianópolis, SC, Brazil, in November 17-20, 2003

\begin{abstract}
The coal mining activity is characterized by the generation of large amount of by-products. One of them is pyrite, which tends to acidify the water, solubilizing heavy metals. As a consequence the environment becomes acid and rich in heavy metals, selecting microorganisms able to survive in this condition, which are of great interest as bioremediation agents. This work describes the isolation and characterization of microorganisms from a coal mining area in Santa Catarina. These microorganisms comprised bacteria, fungi and yeasts resistant to zinc, nickel and cadmium.
\end{abstract}

Key words: heavy metal resistance, coal mining, acidophilic microorganisms, bioremediation.

\section{INTRODUCTION}

The acid mine drainage is one of the main problems associated with coal mining activities. One of the effects is the increase in heavy metal solubility, which results in the accumulation of these toxic elements in the environment. In consequence these sites become inhospitable and just those microorganisms able to tolerate the acidity and the high concentration of heavy metals can survive. Thus, the bioprospection of these natural selected organisms represents an important strategy in order to obtain agents for bioremediation processes (5). The present work describes the isolation and characterization of the heavy metal resistance of microorganisms from coal mining environments of Santa Catarina.

\section{MATERIALS AND METHODS}

\section{Sampling and Sample Preparation}

Samples of water, sediment, soil and plants were collected from pyrite contaminated sites in Capivari de Baixo and Criciúma
(SC - Brazil) and kept in sterilized flasks under refrigeration until processing in laboratory.

\section{Isolation of Microorganisms}

The methods of isolation are summarized in Table 1. Inoculated plates were incubated up to two weeks at $30^{\circ} \mathrm{C}$. Different colonies of bacteria and fungi were selected and purified.

Enrichment experiments using GYA-pH 3 media were also conducted in increasing metal concentrations (up to $100 \mathrm{mM}$ of $\mathrm{Zn}, \mathrm{Ni}, \mathrm{Cd}$ and $\mathrm{Cu}$ ), for selective isolation of metalophilic microorganisms. Incubations were conducted at $30^{\circ} \mathrm{C}$ and 150 rpm by one-week intervals between each metal concentration treatment.

\section{Resistance test}

The isolates were tested for heavy metals $\left(\mathrm{ZnCl}_{2}, \mathrm{NiCl}_{2}, \mathrm{CdCl}_{2}\right.$ and $\mathrm{CuSO}_{4}$ ) resistance as described by Malik and Jaiswal, 2000 (7), using GYA media ( $\mathrm{pH} 4.0$ for acidophilics and 5.5 for the remainders) for bacteria and yeast, and MEA media for filamentous fungi. The concentrations tested were 1, 5, 10 and

*Corresponding author. Mailing address: Laboratório de Microbiologia Aplicada, bl. 20, s1 127, Centro de Ciências Tecnológicas da Terra e do Mar, Universidade do Vale do Itajaí. CP 360, Rua Uruguai, 458. 88302-202, Itajaí, SC, Brasil. Tel.: (+5547) 341-7929. E-mail: marcusadonai@ cctmar.univali.br 
$20 \mathrm{mM}$, except in the filamentous fungi, which was only $10 \mathrm{mM}$, keeping, in all cases, the same incubation conditions as in the isolation procedure.

\section{Lineages Characterization}

Cellular and colony morphology of the isolated strains were characterized using a phase contrast microscope.

\section{RESULTS}

Ninety-six strains of bacteria and fungi were isolated. The bacteria were separated in two groups neutrophilic (growth at neutral $\mathrm{pH}$ ) and acidophilic (growth at acidic $\mathrm{pH}$ ). The neutrophilic group comprised mainly Gram-positive bacteria with four distinct morphologies, while the acidophilic group was composed by Gram-negative bacilli. Yeasts were isolated in acid medium, showing a great morphology diversity. The filamentous fungi were isolated in both acid and neutral medium without any morphological difference.

Distinct patterns of heavy metal resistance were evidenciated (Tables 1 and 2), being the $\mathrm{Zn}$ and $\mathrm{Ni}$ resistance the most widespread. Only the fungi were $\mathrm{Cd}$ resistant, and none of the isolates presented resistance to $\mathrm{Cu}$. The incidence of resistant strains was higher among fungi.

Table 1. Methods for sample processing and isolation of microorganisms. TSA, Tryptic Soy Agar; SA, Saboraud Agar; GYA, Glucose Yeast Extract Agar; MEA, Malt Extract Agar.

\begin{tabular}{ccc}
\hline Sample & Processing & Culture Media \\
\hline Water & Dilution and plating & TSA (pH 7.0), SA (pH 5.5) and GYA (pH 2.5 and 4.0) \\
Sediment and soil & Ressuspension, dilution and plating & TSA (pH 7.0), SA (pH 5.5) and GYA (pH 2.5 and 4.0) \\
Plants & Maceration/fragmentation and plating & MEA (pH 5.5) and GYA (pH 2.5 and 4.0) \\
\hline
\end{tabular}

*All strains were resistant to $\mathrm{ZnCl}_{2}$ and sensitive to $\mathrm{CuSO}_{4}$.

Table 2. Resistance of bacteria and yeast strains to different heavy metals.

\begin{tabular}{|c|c|c|c|}
\hline \multicolumn{2}{|r|}{ Bacteria } & \multicolumn{2}{|r|}{ Yeasts } \\
\hline Strain & Resistance & Strain & Resistance \\
\hline B2 & $1 \mathrm{mM} \mathrm{ZnCl}_{2}$ and $1 \mathrm{mM} \mathrm{NiCl}_{2}$ & B12 & $20 \mathrm{mM} \mathrm{ZnCl}_{2}$ and $1 \mathrm{mM} \mathrm{NiCl}_{2}$ \\
\hline B6 & $1 \mathrm{mM} \mathrm{NiCl}_{2}$ & B15 & $20 \mathrm{mM} \mathrm{ZnCl}_{2}$ and $1 \mathrm{mM} \mathrm{NiCl}_{2}$ \\
\hline YE-05b & $1 \mathrm{mM} \mathrm{NiCl}_{2}$ & B16 & $20 \mathrm{mM} \mathrm{ZnCl}_{2}$ and $1 \mathrm{mM} \mathrm{NiCl}_{2}$ \\
\hline YE-16 & $1 \mathrm{mM} \mathrm{ZnCl}_{2}$ and $1 \mathrm{mM} \mathrm{NiCl}_{2}$ & YE-02 & $10 \mathrm{mM} \mathrm{ZnCl}_{2}$ and $1 \mathrm{mM} \mathrm{NiCl}_{2}$ \\
\hline YE-18 & $1 \mathrm{mM} \mathrm{ZnCl}_{2}$ and $5 \mathrm{mM} \mathrm{NiCl}_{2}$ & YE-05a & $10 \mathrm{mM} \mathrm{ZnCl}_{2}$ \\
\hline CV-25 & $20 \mathrm{mM} \mathrm{ZnCl}_{2}$ & YE-19 & $10 \mathrm{mM} \mathrm{ZnCl}_{2}, 10 \mathrm{mM} \mathrm{NiCl}_{2}$ and $1 \mathrm{mM} \mathrm{CdCl}_{2}$ \\
\hline CV-26 & $10 \mathrm{mM} \mathrm{ZnCl}_{2}$ & YE-20 & $1 \mathrm{mM} \mathrm{ZnCl}{ }_{2}$ and $1 \mathrm{mM} \mathrm{NiCl}_{2}$ \\
\hline CV-33 & $20 \mathrm{mM} \mathrm{ZnCl}_{2}$ & YE-22 & $1 \mathrm{mM} \mathrm{ZnCl}_{2}$ \\
\hline \multirow[t]{2}{*}{ CV-56 } & $1 \mathrm{mM} \mathrm{ZnCl}_{2}$ & YE-23 & $1 \mathrm{mM} \mathrm{ZnCl}_{2}$ \\
\hline & & YE-24 & $1 \mathrm{mM} \mathrm{ZnCl}_{2}$ \\
\hline
\end{tabular}

Table 3. Resistance of filamentous fungi to different heavy metals*.

\begin{tabular}{ccccccccc}
\hline Strain & $\mathbf{N i C l}_{2}$ & $\mathbf{C d C l}_{\mathbf{2}}$ & Strain & $\mathbf{N i C l}_{\mathbf{2}}$ & $\mathbf{C d C l}_{\mathbf{2}}$ & $\mathbf{S t r a i n}$ & $\mathbf{N i C l}_{\mathbf{2}}$ & $\mathbf{C d C l}_{\mathbf{2}}$ \\
\hline $\mathbf{1 1}$ & + & - & $\mathbf{3 4}$ & - & - & $\mathbf{6 0}$ & - & - \\
$\mathbf{1 7}$ & - & - & $\mathbf{3 8}$ & - & - & $\mathbf{6 1}$ & + & - \\
$\mathbf{1 8}$ & - & - & $\mathbf{3 9}$ & + & + & $\mathbf{7 1}$ & - & - \\
$\mathbf{2 4}$ & + & - & $\mathbf{4 9}$ & + & - & $\mathbf{1 0 M}$ & + & - \\
$\mathbf{2 6}$ & + & - & $\mathbf{5 0}$ & + & - & $\mathbf{5 1 P}$ & - & - \\
$\mathbf{3 0}$ & - & - & $\mathbf{5 9}$ & - & - & $\mathbf{D}$ & - & + \\
\hline
\end{tabular}

*All strains were resistant to $\mathrm{ZnCl}_{2}$ and sensitive to $\mathrm{CuSO}_{4}$. 


\section{DISCUSSION}

Heavy metal resistance is a widespread attribute among microorganisms isolated from mining environments. Bacteria from Acidiphilium and Acidocella genera are able to resist to levels as high as $1 \mathrm{M} \mathrm{Cd}, \mathrm{Zn}, \mathrm{Ni}$ and $\mathrm{Cu}$, with this resistance being plasmid- mediated $(3,6)$.

Filamentous fungi and yeasts can also show high levels of metals and metalloids resistance, being this resistance associated to the capacity to accumulate these elements $(1,2,4,8)$. This work evaluated a great number of strains of different microorganisms, and in general, the incidence of heavy metal resistance was higher among fungi. However, except for $\mathrm{Cd}$, the resistance levels were similar to those of bacteria. For fungi, the detected resistance levels were similar to those related by Durán et al., 1999 (2), except in the case of Zn, which was lower.

Results of this study showed that heavy metal resistance among bacteria is widespread. The strains isolated by enrichment procedures showed an extreme tolerance (up to $100 \mathrm{mM}$ ) to the tested metals (except $\mathrm{Cu}$ ), which is in agreement with results of other studies.

The high incidence of heavy metal resistance detected in this work indicates the potential of these microorganisms as bioremediation agents.

\section{RESUMO}

\section{Resistência a metais pesados em microrganismos isolados de ambientes da mineração do carvão de Santa Catarina}

A atividade de mineração do carvão é responsável pela geração de diferentes sub-produtos. Entre esses, está a pirita que acidifica a água e acelera o processo de solubilização de metais. Como consequiência, o ambiente torna-se ácido e rico em metais pesados, os quais selecionam os microrganismos capazes de sobreviver nestas condições. Esses microrganismos podem, por sua vez, serem empregados como agentes para a biorremediação de áreas contaminadas com metais pesados. No presente trabalho é descrito o isolamento e a caracterização de bactérias, fungos e leveduras resistentes aos metais zinco, níquel e cádmio.

Palavras-chave: resistência a metais pesados; mineração do carvão; microrganismos acidofílicos; biorremediação.

\section{REFERENCES}

1. Cánovas, D.; Durán, C.; Rodríguez, N.; Amils, R.; Lorenzo, V. Testing the limits of biological tolerance to arsenic in a fungus isolated from the River Tinto. Environ. Microbiol., 5(2):133-138, 2003.

2. Durán, C.; Marín, I.; Amils, R. Specific metal sequestering acidophilic fungi. In: Amils, R.; Ballester, A. (eds). Biohydrometallurgy and the Environment Toward the Mining of the $21^{\text {st }}$ Century. Elsevier, Amsterdam, 1999, p.521-530.

3. Ghosh, S.; Mahapatra, N.R.; Banerjee, P.C. Metal resistance in Acidocella strains and plasmid-mediated transfer of this characteristic to Acidiphilium multivorum and Escherichia coli. Appl. Environ. Microbiol., 63(11):4523-4527, 1997.

4. Itoh, S.; Iwaki, M.; Wakao, N.; Yoshizu, K.; Aoki, A.; Tazaki, K. Accumulation of $\mathrm{Fe}, \mathrm{Cr}$ and $\mathrm{Ni}$ metal inside cells of acidophilic bacterium Acidiphilium rubrum that produces Zn-containing bacteriochlorophyll a. Plant Cell Physiol., 39(7):740-744, 1998.

5. Ledin, M.; Pedersen, K. The environmental impact of mine wastes - roles of microorganisms and their significance in treatment of mine wastes. Earth-Sci. Rev., 41:67-108, 1996.

6. Mahapatra, N.R.; Banerjee, P.C. Extreme tolerance to cadmium and high resistance to copper, nickel and zinc in different Acidiphilium strains. Lett. Appl. Microbiol., 23:393-397, 1996.

7. Malik, A.; Jaiswal, R. Metal resistance in Pseudomonas strains isolated from soil treated with industrial wastewater. World J. Microbiol. Biotechnol., 16:177-182, 2000.

8. Silóniz, M.; Payo, E.M.; Callejo, M.A.; Marquina, D.; Peinado, J.M Environmental adaptation factors of two yeasts isolated from the leachate of a uranium mineral heap. FEMS Microbiol. Lett., 210:233237, 2002. 